\title{
LUZES E FARPAS SOB OS CAMAROTES: ROUSSEAU, RAMEAU E A QUERELA DOS BUFÕES'
}

\section{EXCHANGING BARBS UNDER THE THEATER BOXES: ROUSSEAU, RAMEAU AND THE QUERELLE DES BOUFFONS}

Fabio Stieltjes Yasoshima Universidade de São Paulo fabioyasoshima@gmail.com 


\section{Resumo}

Frequentemente, os inflamados debates estético-musicais que estiveram em pauta na França da segunda metade do século XVIII e que deram origem ao episódio conhecido como Querela dos Bufões foram reduzidos a um curioso anedotário ou a uma guerra panfletária produzida tão somente pelos humores de seus aguerridos combatentes, os quais, postados sob os camarotes reais e divididos em defensores da tradição musical francesa e entusiastas da música italiana, disparavam críticas mútuas, sob a forma de panfletos, a exemplo das farpas lançadas por Jean-Jacques Rousseau, filósofo e músico autodidata, contra os partidários da música francesa e, especialmente, contra seu arqui-inimigo na cena musical da llustração, o renomado compositor e teórico da música Jean-Philippe Rameau. No presente artigo, para além da reconstituição histórica da famosa Guerra dos Bufões, procedemos à análise dos próprios argumentos apresentados por Rousseau em sua ardorosa, porém articulada defesa da ópera italiana em contraposição à ópera versalhesa, tais como aqueles expostos em sua Carta sobre a música francesa.

Palavras-chave: Estética musical; Querela dos Bufões; Jean-Jacques Rousseau; Jean-Philippe Rameau.

\section{Abstract}

The enthusiastic aesthetic debates that were on the agenda in France in the second half of the 18th century and which gave rise to the episode known as Querelle des Bouffons were often reduced to a pamphlet war produced only by the moods of its combatants posted under the theater boxes, and divided into defenders of the French musical tradition and enthusiasts of Italian music, fired mutual criticisms in the form of pamphlets, such as the splinters launched by the self-taught musician and philosopher Jean-Jacques Rousseau against the partisans of French music, especially against his arch-enemy in the Enlightenment music scene, the renowned composer and music theorist JeanPhilippe Rameau. In the present article, far from making a historical reconstruction of the famous Guerre des Bouffons, we seek to analyze the arguments presented by Rousseau in his ardent, but articulate defense of Italian opera as opposed to Versailles opera, such as those set out in his Letter on French music.

Keywords: Musical Aesthetics; Querelle des Bouffons; Jean-Jacques Rousseau; Jean-Philippe Rameau.

\footnotetext{
10 presente artigo foi realizado com o apoio do Conselho Nacional de Desenvolvimento Científico e Tecnológico (CNPq, Brasil).

2 Doutor, mestre e bacharel em Filosofia pela Universidade de São Paulo (FFLCH-USP). É autor da primeira tradução parcial do Dicionário de música (1768) de Jean-Jacques Rousseau para o português (edição no prelo), objeto de estudo de sua dissertação de mestrado e, em parte, de sua tese de doutorado. Como pesquisador, tem se dedicado ao estudo da Filosofia Moderna e da Estética (sobretudo a da Música) e à tradução de textos de autores do século das Luzes e de outros períodos.
} 
Desde a infância, amei a música francesa, a única que conhecia; ouvi música na Itália e amei-a sem desgostar da outra, a preferência recaía sempre sobre a que ouvia por último. Foi somente após ter ouvido ambas no mesmo dia, no mesmo teatro, que a ilusão se desvaneceu e senti até que ponto o hábito pode fascinar a natureza e fazer-nos considerar bom o que é mau, e belo o que é horrivel. (ROUSSEAU, 2009, p.64-65).

Cerca de sete anos após a malograda apresentação de seu balé heroico intitulado As musas galantes 3 (1745), Jean-Jacques Rousseau (1712-1778), filósofo e músico autodidata, envolve-se em uma das mais acaloradas disputas travadas no âmbito da estética musical das Luzes: a famosa Querelle des Bouffons (também conhecida como Guerre des Bouffons), a qual também se revelou como um dos momentos cruciais de seu embate contra o mais importante teórico da música desse período, o célebre compositor dijonês Jean-Philippe Rameau (1683-1764).

Se seguirmos certas interpretações que, já no século das Luzes, começaram a surgir dessa grande querela, veremos que é possível compreender essa oposição entre partidários da música italiana versus partidários da música francesa como um antigo debate reacendido. Ora, isso se deve ao fato de que, por um lado, nesse mesmo debate, se percebeu um eco da Querela dos Antigos e Modernos; ${ }^{4}$ por outro lado, sustentou-se que a comparação entre as duas músicas - italiana e francesa - já havia sido inaugurada no início do século XVIII, com François Raguenet (1660-1722), com seu Paralèle des italiens et des françois, en ce qui regarde la musique et les opéra ${ }^{5}$ (Paris, 1702), no qual elogiara a música italiana e tecera críticas à música francesa, e sua posterior Défense du Parallèle des italiens et des françois, en ce qui regarde la musique et les opéra (Paris, 1705), desencadeada pelos ataques que vinha sofrendo de Jean Laurent Lecerf de La Viéville (1674-1707), o qual, irritado com a publicação do "paralelo" de Raguenet, tomara partido da música francesa e pusera-se a escrever, de maneira intermitente, sua Comparaison de la musique italienne et de la musique françoise (1704-1706). Com efeito, como bem lembram Jean e Brigitte Massin,

Seis meses antes da chegada dos Bufões a Paris, o barão de Grimm, em um texto que foi durante muito tempo considerado como o primeiro ato da nossa Querela, sublinhou: "A música italiana promete e proporciona prazer a todo homem que possui ouvido" (Lettre sur Omphale, fevereiro de 1752). Isto não era novidade. Atualmente, parece que essa epístola é apenas peça a ser arquivada do dossiê

3 François Jacob sugere que os três primeiros fracassos da vida de Jean-Jacques teriam ocorrido no âmbito musical: o fracasso retumbante de sua apresentação musical na casa do sr. de Treytorens, professor de Direito e amante de música (episódio conhecido como o "concerto de Lausanne", o qual foi relatado no Livro IV das Confissões), e os dois episódios que envolveram "ataques" públicos de Rameau, quais sejam, a apresentação de seu novo projeto de notação musical e a primeira audição de seu balé intitulado Les Muses galantes (JACOB, 2012, p.67; ver também ROUSSEAU, 2008, p.153-154).

$4 \quad$ Como bem lembra Marc Fumaroli: "A Querela dos Antigos e dos Modernos, no fim do reinado de Luís XIV (o 'fim da Antiguidade', segundo Joubert), transforma-se em um grande debate da arte com as técnicas, do gênio com o método, da visão poética com a univocidade da dedução lógica. Os Antigos do mundo greco-romano tornam-se assim as testemunhas da arte, do gênio, da generosidade poética, da variedade e da verdade humanas, ao passo que os Modernos, contemporâneos da ciência, do método, da razão crítica, já não podem mais esperar encontrar o princípio esquecido de um conhecimento perdido, a não ser em sua própria infância" (FUMAROLI, 2001, p.203). 
"música italiana contra música francesa" - dossiê que o abade Raguenet havia aberto em 1702, posicionando-se na questão com habilidade. Como continuasse em aberto, a querela apenas aguardava para ressurgir. (MASSIN, 1985, p.541).

Segundo Alain Cernuschi (2012, p.182 et seq.), a esse debate entre Raguenet e Lecerf de La Viéville, seguiram-se outras obras de autores (Grandval, Saint-Mard e Mably, entre outros) que também sustentaram a comparação entre as duas músicas, e Rousseau não somente estava a par de todas essas discussões, mas se serviu delas para escrever o esboço de um texto - provavelmente composto em 1744 ou 1745 - que permaneceu inacabado e foi postumamente intitulado Lettre sur l'opéra italien et français ${ }^{6}$ ("Carta sobre a ópera italiana e francesa"). Um dos elementos mais curiosos desse esboço de texto não é propriamente a defesa da ópera francesa - pois sabemos que, antes de conhecer a Itália, Rousseau fora um grande admirador da tradição musical da França -, mas o fato de seu autor ter iniciado sua composição após retornar de Veneza, onde seus sentidos haviam se alterado de tal maneira que o filósofo passaria a defender a música italiana com inextinguível fervor e entusiasmo. ${ }^{7}$ Mas talvez o aspecto mais relevante da referida carta resida precisamente no que apontou Cernuschi, segundo o qual esse texto inacabado testemunharia, já em 1745, "um primeiro estádio do pensamento estético-musical de Rousseau", uma espécie de prelúdio reflexivo no qual, partindo da leitura dos documentos desse antigo dossiê música italiana contra música francesa (sobretudo de Raguenet), nosso filósofo-músico teria se investido de uma "perspectiva comparatista" que se tornaria, dali em diante, cada vez mais aguçada em seus escritos musicais (CERNUSCHI, 2012, p.175 et seq.).

Como bem observa Kühl, no estudo introdutório de sua tradução do "Paralelo" de Raguenet, alguns autores, como o abade Irail, em suas Querelles Litéraires, de 1761, procuraram mostrar que "Raguenet estaria na origem da Querela dos Bufões". Kühl também observa que, "já no final da polêmica, o texto de Raguenet é republicado postumamente, desta vez com o título $A$ paz da ópera ou paralelo imparcial da música francesa e da música italiana" (KÜHL, 2014, p.160-161). Ora, essa "nova publicação de 1753 não é uma mera reedição do texto com um novo título", sustenta Kühl, e sim a reedição de um texto com expressivas variações.

\footnotetext{
6 Segundo Olivier Pot, este manuscrito, embora não tenha saído do estádio de esboço, pode ser considerado como a "primeira crítica de estética musical" de Rousseau (POT, 1995, p.LXXVII).

7 Sobre a estada de Rousseau em Veneza e as impressões musicais que ficariam marcadas na memória do filósofo, podemos formar alguma ideia, por exemplo, a partir da seguinte passagem das Confissões: "Não deixemos Veneza sem dizer alguma coisa sobre os célebres divertimentos dessa cidade, ou pelo menos da pequeníssima parte que conheci na minha estada lá. [...] Eu trouxera de Paris o preconceito que lá existe contra a música italiana; mas recebera também da natureza essa sensibilidade de tato contra a qual os preconceitos nada podem. Depressa adquiri por essa música a paixão que ela inspira a todos que são feitos para a compreender. Ao escutar uma barcarola [canção de gondoleiros venezianos], parecia-me que até então nunca ouvira cantar; e, logo, de tal forma me apaixonei pela ópera, que aborrecido de tagarelar, comer e brincar nos camarotes, quando só queria ouvir, fugia à companhia dos outros para ir para um outro lado. Lá, sozinho, trancado no camarote, apesar do comprimento do espetáculo, entregava-me ao prazer de gozá-lo à vontade até o fim. Um dia, no teatro de São Crisóstomo, adormeci, e mais profundamente do que se estivesse na cama. As árias ruidosas e brilhantes não me despertaram; mas quem poderia descrever a sensação deliciosa que me fez sentir a doce harmonia e os cantos angélicos da ária que me acordou? Que despertar, que deslumbramento, que êxtase quando abri ao mesmo tempo os ouvidos e os olhos! Minha primeira ideia foi me supor no paraíso. Aquele trecho encantador, que recordo ainda, e que não esquecerei em vida minha, começava assim: Conservami la bela / Che si m'accende il cor. Quis possuir este trecho. E possuí-o, guardei-o muito tempo. No papel, porém, não estava como na minha memória. Era a mesma nota, mas não era a mesma coisa. Nunca mais essa ária divina pôde ser executada, senão em minha cabeça, como o foi, com efeito, no dia em que me despertou" (ROUSSEAU, 2008, p.289-290).
} 
A começar pelo título, a nova versão parece responder a La Guerre de l'Opéra, de Jacques Cazotte, publicado anonimamente em 1753 (CAZOTTE, 1753). O texto de Cazotte aparece como uma tentativa "neutra" de identificar os dois lados da polêmica, o francês e o italiano, inclusive com a contabilização dos "mortos e feridos" [...]. Mas certamente o novo título do livro de Raguenet assume um caráter conciliatório e pacificador da "guerra". (KÜHL, 2014, p.161).

Não nos cabe, aqui, empreender uma reconstituição histórica da Querela ou da Guerra dos Bufões, nem de seus prováveis antecedentes. Muitos autores com cabedal histórico, musicológico e filosófico já o fizeram brilhantemente. ${ }^{8}$ Não é tampouco a cronologia desse episódio que nos interessa aqui, mas, sobretudo, a troca de farpas e a estopilha que foram algumas das críticas de Rousseau contra a tradição musical francesa (representada, sobretudo, por Rameau), as quais surgiram durante essa "guerra" entre tantas outras do mundo cultural setecentista ${ }^{9}-$, e os traços que ela teria deixado no pensamento do filósofo genebrino.

Franklin de Matos resume muito bem o famoso conflito que ora evocamos:

Essa disputa (1752-1754), que dividiu os homens de letras parisienses entre partidários da ópera italiana e da francesa, é evocada principalmente pelos historiadores da música, mas encerra também uma controvérsia sobre teatro e ainda outra, mais geral, sobre "estética". Ao criticarem a tradição musical francesa por sua ênfase na harmonia, em detrimento da melodia, e ao elogiarem a melodia italiana por seu poder de expressar as paixões, os enciclopedistas desqualificavam ao mesmo tempo a ópera-balé versalhesa, pomposa e mitológica, em nome da simplicidade e despojamento do modelo italiano de Pergolesi [...]. (MATOS, 2001, p.25).

\title{
Com efeito, Rousseau se refere a Pergolesi em sua Carta a Grimm, ${ }^{10}$ de 1752, e, na
}

\begin{abstract}
8 Entre os autores que se dedicaram ao estudo minucioso da Querela dos Bufões, seja do ponto de vista da historiografia musical, seja do ponto de vista da estética, destacamos Denise Launay e Andrea Fabiano (LAUNAY, 1973; FABIANO, 2005). Em sua História da música, Hugo Riemann fez um procedente balanço dos acontecimentos da famosa Guerra dos Bufões - contabilizando também a querela entre os lullistas e ramistas ou "ramoneurs" - e de alguns de seus mais importantes desdobramentos: "[...] não se pode negar que a música italiana tenha exercido certa influência na música de Rameau, e, por isso, a princípio, ele atraiu uma grande oposição por parte de seus compatriotas, que o acusaram de querer italianizar a ópera francesa. Mais tarde foi, como Lully, enaltecido como compositor puramente nacional. Mas não passou muito tempo sem que a música italiana tentasse outra vez entrar em Paris sob a forma de opera buffa, criada neste tempo por Nicolo Logroscino (nascido em 1700, em Nápoles; morto em 1763, na mesma cidade) e Giovanni Battista Pergolesi (nascido em 1710, em Jesi; morto em 1736, em Pozzuoli). Em 1752, uma companhia bufa italiana obteve a permissão para representar em Paris, e as óperas de Pergolesi representadas por eles, La serva padrona e Il maestro di musica, tiveram tal êxito que Paris dividiu-se em dois partidos: buffonistas e antibuffonistas, estes últimos, defensores da ópera nacional francesa. Dois anos depois, os italianos tiveram de abandonar Paris; mas, devido à impressão que a ópera bufa italiana deixou, nasceu ali a opéra-comique francesa, a comédia com cantos, cujos mais notáveis representantes foram François André Danican-Philidor (17261795), Pierre Alexandre Monsigny (1729-1817) e André Ernest Modeste Grétry (1741-1813). [...] É inegável que a criação da ópera bufa foi um processo de rejuvenescimento da ópera italiana. Às composições feitas, por assim dizer, a partir de um modelo de ópera, sobre assuntos antigos de história ou mitologia, que em definitivo não serviam mais que de mesquinho pretexto às acrobacias vocais dos primi uomini (castrat) e das prime donne, aqui se contrapôs a verdadeira vida dramática; e tudo se passou de modo que a ópera bufa exerceu inevitavelmente uma influência sobre a ópera séria, seja com a entrada de figuras e episódios cômicos (ópera semiseria), seja com a transmissão à grande ópera de novas formas, às quais a ópera cômica havia dado origem (ensemble dramático, final, ária em forma de rondó etc.)" (RIEMANN, 1959, p.382-384).
\end{abstract}

9 Referimo-nos, de modo geral, às "tensões extremamente vivas" que, segundo o historiador Antoine de Baecque, durante todo o século XVIII, percorreram o "mundo cultural", "às vezes estourando em guerras intestinas violentas e devastadoras, arruinando as reputações, revelando talentos polêmicos, focalizando o debate em temas e gêneros em voga" (BAECQUE; MELONIO, 2005, p.81).

10 Lettre à M. Grimm, au sujet des remarques ajoutées à sa Lettre sur Omphale ("Carta ao sr. Grimm, a propósito das observações acrescentadas a sua Carta sobre Ônfale"). Escrito em 1752, este texto - que veio a lume anonimamente, e no qual seu autor sai em defesa de Friedrich 


\begin{abstract}
Enciclopédia, no verbete "Compositor", por exemplo. ${ }^{11}$ É nesta mesma Carta a Grimm, publicada pouco antes do estopim da Guerra dos Bufões, que Rousseau dirige a Rameau uma espécie de "elogio ultrajante" (para emprestarmos a expressão que, como vimos, o próprio Rousseau utilizaria para classificar a apreciação feita por Rameau sobre suas Musas galantes). Vale a pena seguirmos esta longa passagem da Carta a Grimm, na qual Rousseau se arma de uma retórica que, como aponta Boccadoro, visa precisamente "rebaixar os méritos" de seu rival:
\end{abstract}

As obras teóricas do sr. Rameau possuem isto de muito singular: que elas fizeram um grande sucesso sem terem sido lidas; e doravante o serão muito menos, desde que um filósofo ${ }^{12}$ se deu ao trabalho de escrever o resumo da doutrina deste autor. Certo é que este compêndio anulará os originais; e, com tal reparação, não teremos nenhum motivo de lamentá-los. Essas diferentes obras não contêm nada de novo nem de útil, a não ser o princípio do baixo fundamental; mas não é pouca coisa ter apresentado um princípio, mesmo que ele seja arbitrário, a uma arte que parecia não possuí-lo, e de ter facilitado tanto as suas regras de modo que o estudo da composição, que outrora era uma ocupação de vinte anos, atualmente é tarefa para alguns meses. Os músicos apreenderam avidamente a descoberta do sr. Rameau, afetando desprezá-la. Os alunos multiplicaram-se com uma rapidez surpreendente; por todos os lados só se viam autorezinhos efêmeros, a maior parte sem talentos, que posavam de doutores à custa de seu mestre; e os préstimos bem reais, muito grandes e muito sólidos que o sr. Rameau ofereceu à música, trouxeram ao mesmo tempo este inconveniente: que a França se encontrou inundada de música ruim e de maus músicos. Pois cada um deles, acreditando conhecer todas as sutilezas da arte, assim que conhecia os seus elementos, todos se meteram a fazer harmonia, antes que o ouvido e a experiência lhes ensinassem a discernir a boa. No que diz respeito às óperas do sr. Rameau, antes de tudo, a elas devemos o favor de terem sido as primeiras a elevar o teatro da ópera acima dos estrados [da região] da Pont-

Melchior Grimm (1723-1807) -, publicado meses antes do estopim da Querela dos Bufões, remete o leitor a outras duas cartas que fazem parte da controvérsia entre Grimm, este homem de letras alemão que vivia em Paris, o qual assina a Lettre sur "Omphale" ("Carta sobre Ônfale", na qual hostilizava a música francesa), publicada neste mesmo ano no Mercure de France, e um crítico anônimo - provavelmente o Abade Raynal -, que publica em seguida as suas Observações a propósito da carta do sr. Grimm sobre Ônfale. Cabe aqui lembrar que Omphale ("Ônfale") foi uma tragédia lírica, em um prólogo e cinco atos, composta pelo parisiense André Cardinal Destouches (1672-1749). Representada pela primeira vez na Academia Real de Música (da qual Destouches chegou a ser diretor), em Paris, a 10 de novembro de 1701 (e, após esta data, reapresentada pelo menos quatro vezes até 1752, quando, como observa Brenno Boccadoro, "cinquenta anos após a primeira representação, ela suscita uma violenta polêmica"), Omphale teve seu libreto escrito pelo também parisiense Antoine Houdar de La Motte (1672-1731), poeta dramático e lírico e teórico do teatro que considerava a ópera de seu país, segundo Kintzler, como "um modelo poético com o mesmo valor que o do teatro dramático", e a quem Rameau destina sua Carta de 1727, na qual o compositor "expõe suas concepções líricas" (KINTZLER, 1992, p.382; ver também BOCCADORO, 2012, p.207).

11 Giovanni Battista Pergolesi (1710-1736), natural de Jesi, foi um dos compositores mais apreciados por Rousseau, ao lado de outros nomes da escola napolitana, como Leonardo Vinci (c.1690-1730) e Leonardo Leo (1694-1744). Entre as obras de Pergolesi destacam-se seu Stabat Mater (1736) e o intermezzo intitulado La Serva Padrona (1733), com o qual a companhia dos Bufões estreou na "guerra" das óperas, o que teria ocorrido precisamente no dia $1^{\circ}$ de agosto de 1752, como bem lembra Raymond Trousson, em nota às Confissões de Rousseau (ROUSSEAU, 2012a, p.515, n. 5). Em seu Dicionário de música (1768), no qual remanejou e ampliou sobremodo os verbetes que escrevera para a Enciclopédia, Rousseau cita Pergolesi nos verbetes "Compositor", "Desenho", "Gênio", "Ópera”, "Estilo”, entre outros. Uma porção substancial dos verbetes sobre música escritos por Rousseau para a Enciclopédia encontra-se no volume 5 da edição brasileira, empreitada editorial de Diderot e d'Alembert (DIDEROT, 2015b).

12 Trata-se, aqui, do matemático, filósofo e coeditor da Enciclopédia, o já mencionado Jean Le Rond d’Alembert, cujo nome figura em uma nota a esta passagem, segundo Brenno Boccadoro, na versão de Neuchâtel. Como bem lembra Boccadoro (em nota a Carta a Grimm), a colaboração de d'Alembert, ou melhor, sua contribuição para a "reorganização dos escritos de Rameau remonta ao Relatório da demonstração do principio da harmonia extraído dos Registros da Academia Real de Ciências, de 10 de dezembro de 1749. Em seguida vêm as duas edições dos Elementos de música teórica e prática segundo os princípios do sr. Rameau, publicadas em Paris nos anos de 1752 e 1762" (ROUSSEAU, 2012b, p.227, n. 2). 
-Neuf. ${ }^{13}$ Ele transpôs corajosamente o pequeno círculo de musiqueta em torno do qual nossos musicastros giravam incessantemente desde a morte do grande Lully. De sorte que, quando alguém for assaz injusto para recusar talentos superiores ao sr. Rameau, pelo menos haverá de convir que ele the abriu o caminho de alguma maneira, e que ele colocou os músicos que virão depois dele em condições de ostentar impunemente os seus; o que certamente não era uma empresa fácil. Ele sentiu os espinhos, seus sucessores colherão as rosas. (ROUSSEAU, 2012b, p.227-228).

Para adentrarmos sem mais retardo na grande Querela, lembremos como, no oitavo livro de suas Confissões, Rousseau descortina a ruidosa cena na qual os dois partidos digladiavam sob os camarotes reais:

Paris toda se dividiu em dois partidos, mais encarniçados do que se se tratas-
se de um negócio de Estado ou de religião. O mais poderoso, mais numeroso,
composto dos grandes, dos ricos e das mulheres, lutava pela música francesa; o
outro, mais vivo, mais altivo, mais entusiasta, era composto por conhecedores
de verdade, por gente de talento, homens de gênio. Seu pequeno pelotão se
reunia na Ópera, sob o camarote da rainha. A outra parte enchia todo o resto
da plateia e da sala, mas o seu ponto principal era sob o camarote do rei. Foi daí
que vieram esses nomes célebres de partidos "lado do rei" e "lado da rainha". A
disputa, animando-se, produzia várias brochuras. (ROUSSEAU, 2008, p.350-351).

De fato, a Querela dos Bufões configurou-se a partir da chegada a Paris, em agosto de 1752, de uma companhia italiana de ópera bufa, liderada pelo compositor Eustachio Bambini (1697-1770), e da posterior formação de dois partidos opostos, a saber: o partido da Rainha, o qual se posicionou em defesa da companhia estrangeira (a favor, portanto, da ópera italiana), e o partido cujo representante mais ilustre foi sem dúvida alguma Rameau, o chamado partido do Rei, que, por sua vez, defendia a ópera nacional, i.e., a música francesa (BORREL, 2001, p.26-39; MASSIN, 1985, p.540-545; REBATET, 1995, p.245-250; LANDORMY, s.d., cap. IX; COELHO, 1999, p.49-52).

Sabemos que Rousseau, junto com um grupo de enciclopedistas, ${ }^{14}$ tomou o partido da música italiana, ocupando assim um lugar privilegiado entre as vozes exaltadas daqueles que defendiam a trupe dos Bufões. Rameau, naturalmente, posicionou-se no canto do rei (coin du Roi), apoiado por seus compatriotas que defendiam a tradição musical nacional. O debate chegou ao seu ponto culminante quando da publicação da Carta sobre a música francesa, escrita por Rousseau em $1752,{ }^{15}$ na qual o filósofo desqualifica a tradição musical da França de maneira bastante incisiva.

Ora, devemos ter cuidado ao enfatizar essa ardente defesa e receptividade da música italiana por parte dos enciclopedistas e, sobretudo, de Rousseau, pois, como bem lembra Olivier Pot (em nota à Carta sobre a música francesa), mesmo antes da chegada

\footnotetext{
13

Onde ficava o théâtre de la Foire, no qual Rameau debutara sua carreira de compositor, ao escrever música de cena para farsas teatrais, segundo nota de Boccadoro (à Carta a Grimm), o qual também salienta "a retórica de Rousseau", que "visa rebaixar os méritos de Rameau ao medir sua excelência a partir dos níveis mais medíocres da atividade musical" (ROUSSEAU, 2012b, p.228, n. 2).

14 Sobretudo Diderot, d'Alembert e Grimm, ainda que, sem dúvida alguma, o mais aguerrido tenha sido Rousseau.

15 Embora tenha aparecido somente em 1753, justamente durante o ponto alto da querela (KINTZLER, 1993, p.5).
} 
a Paris da companhia de Bambini, pode-se dizer que era um "lugar-comum opor a frieza do público francês ao entusiasmo delirante dos italianos". Ainda segundo Pot, entre os autores que sustentaram essa oposição, destacam-se os testemunhos de Raguenet, De Brosses, Grimm e Du Bos (POT, 1995, p.1468, n. 5).

Apesar de sua participação na querela ter sido mais emblemática que efetiva - na medida em que representava, aos olhos de Rousseau e dos enciclopedistas, o bastião da música francesa -, Rameau também não deixou de lançar suas farpas, em um único libelo, a saber: as "Observações sobre nosso instinto para a música". ${ }^{16}$ De fato, as Observações de Rameau, como bem lembra Sylvie Bouissou, possuíam dois objetivos principais: o primeiro era confirmar e desenvolver a tese exposta em um escrito anterior, ${ }^{17}$ segundo a qual "as regras do princípio sonoro seriam comuns não somente a todas as artes de gosto, mas também às ciências" (BOUISSOU, 2014, p.951). O segundo objetivo das Observações, ainda conforme Bouissou, foi uma tentativa de reagir à violência dos golpes disparados por Rousseau contra a música francesa, ${ }^{18}$ ataques esses cuja toada começa, por exemplo, com esta comparação:

Fiz outra experiência que exige menos precaução, e que vos parecerá, talvez, mais decisiva. Dei a cantar aos italianos as mais belas árias de Lully e, aos músicos franceses, as árias de Leo e de Pergolesi, e observei que, embora estes últimos estivessem muito distantes de apreender o verdadeiro gosto desses fragmentos, sentiam, no entanto, a melodia, e dela tiravam, à sua maneira, frases musicais cantantes, agradáveis e bem cadenciadas. Mas os italianos, solfejando com muita exatidão nossas árias mais comoventes, não puderam jamais identificar nelas nem as frases nem o canto; essa não era para eles uma música com sentido, mas apenas sequências de notas dispostas sem critério e como que por acaso; eles as cantavam precisamente como vós leríeis palavras árabes escritas em caracteres franceses. (ROUSSEAU, 2005, p.17-18).

17 Trata-se de um texto de 1752, o qual foi publicado em Paris com o título de Nouvelles réflexions de M. Rameau sur sa démonstration du principe de l'Harmonie, servant de base à tout l'art musical théorique et pratique ("Novas reflexões do sr. Rameau sobre sua demonstração do princípio da Harmonia, servindo de base ao conjunto da arte musical teórica e prática") (RAMEAU, 2008, p.183-206). Vale lembrar que a mesma tese Ihe granjearia a desconfiança de d'Alembert, o qual, a partir de então, afastar-se-ia cada vez mais dos princípios do compositor que homenageara em seu "Discurso preliminar" da Enciclopédia (DIDEROT, 2015, p.42-265).

18 Tais como a análise crítica do famoso monólogo "Enfin, il est en ma puissance", de Armide, personagem da ópera homônima de Lully, em um prólogo e cinco atos, com libreto de Quinault, representada pela primeira vez em 1686. Em sua Carta, o filósofo assim resume sua análise do monólogo de Armide: "Para resumir em poucas palavras minha opinião sobre o célebre monólogo, digo que, se o considerarmos como canto, não encontraremos nele nem ritmo, nem caráter, nem melodia; se quisermos que seja um recitativo, não encontraremos nem naturalidade, nem expressão; e, qualquer que seja o nome que quisermos lhe dar, vemo-lo cheio de sons prolongados, de trilos e outros ornamentos vocais ainda mais ridículos em uma tal situação do que normalmente o são na música francesa. Sua modulação é regular, mas por isso mesmo pueril, escolástica, sem energia, sem afecção sensível. 0 acompanhamento se limita ao baixo-contínuo, em uma situação em que todo o poder da música deveria ser mobilizado, e esse baixo é mais próximo ao que se proporia a um estudante em sua lição de música que ao acompanhamento de uma cena viva de ópera, cuja textura instrumental deve ser escolhida e aplicada com um sutil discernimento para tornar a declamação mais sensível e a expressão mais viva. Em duas palavras, se nos déssemos ao trabalho de executar a música dessa cena sem juntar-lhe as palavras, sem gritar nem gesticular, não seria possível distinguir nela nada de semelhante à situação que ela pretende representar e aos sentimentos que quer exprimir, e tudo não parecerá senão uma tediosa sequência de sons modulada ao acaso e apenas para fazê-la durar. No entanto, esse monólogo sempre fez, e não duvido que ainda viesse a fazer um grande efeito no teatro, porque seus versos são admiráveis e a situação, viva e interessante. Mas sem os braços e os gestos da atriz, estou persuadido de que ninguém poderia suportar o recitativo, e que esse tipo de música tem grande necessidade do auxílio dos olhos para poder ser suportável aos ouvidos" (ROUSSEAU, 2005, p.43-44). 
Sabemos que, ao rememorar os panfletos publicados durante a Querelle des Bouffons, Rousseau atribui um valor extremado à Carta de sua autoria, como ele próprio deixa claro no Livro VIII das Confissões (que teria sido escrito mais ou menos quinze anos após o término da mesma querela): "O lado do rei quis fazer troça; e foi troçado pelo Pequeno Profeta. Quis meter-se a arrazoar, e foi esmagado pela Carta sobre a música francesa. Esses dois escritos, um de Grimm, outro meu, foram os únicos que sobreviveram à questão; os outros todos já estão mortos" (ROUSSEAU, 2008, p.351).

É também em um curioso relato das Confissões que encontramos a anedota sobre a recepção desse panfleto, na qual transparece claramente o "excesso" de Rousseau, quando este afirma, por exemplo, que os músicos da Ópera teriam maquinado meios de matá-lo na saída do teatro. Vejamos como o autor dessas Confissões caracteriza a trama em questão:

\begin{abstract}
O Pequeno Profeta que, malgrado meu, obstinaram-se muito tempo em me atribuir, foi levado na troça, e não custou o menor incômodo ao seu autor. Mas a Carta sobre a música [francesa] foi tomada a sério, e levantou-se contra mim toda a nação, que se supunha ofendida na sua música. Seria digno da pena de Tácito a descrição do efeito incrível dessa brochura. Era no tempo da grande questão do parlamento com o clero. O parlamento acabava de ser exilado; a fermentação estava no auge; tudo ameaçava um levante próximo. Apareceu a brochura, e no mesmo instante foi esquecida a questão; só se pensou no perigo em que estava a música francesa, e não houve mais levante senão contra mim. Foi ele de tal forma que a nação ainda não se repôs de todo. Na corte, hesitava-se entre a Bastilha e o exílio; e a ordem de prisão teria sido expedida se o sr. de Voyer não the mostrasse o ridículo. Quem ler que essa brochura talvez tenha impedido uma revolução, pensará que sonha; é entretanto uma verdade bem real, que toda Paris ainda pode atestar, pois ainda não se passaram quinze anos depois dessa singular questão. (ROUSSEAU, 2008, p.351).
\end{abstract}

Certo é que a famigerada carta lhe rendeu, à época, um caudaloso coro de injúrias: "[...] se não atentaram contra a minha liberdade, pelo menos não me pouparam insultos; minha própria vida correu perigo", dramatiza Rousseau. "A orquestra da Ópera fez a honesta conspirata de me assassinar à saída", continua o filósofo, ao relatar este "entreato" da Querela do Bufões, no qual convida seus leitores a assistir a uma espécie de teatralização dos fatos. "Contaram-me; tornei-me ainda mais assíduo à ópera e só muito tempo depois soube que o sr. Ancelet, oficial dos mosqueteiros, que me tinha amizade, poupou-me do complô, fazendo-me escoltar, a minha revelia, à saída da ópera" (ROUSSEAU, 2008, p.351). Tais foram, segundo Rousseau, os desdobramentos dessa querela que teria provocado a divisão de toda Paris em dois partidos que, como vimos, aos olhos do filósofo pareciam "mais encarniçados do que se se tratasse de um negócio de Estado ou de religião" (ROUSSEAU, 2008, p.350).

Mas voltemos à explosiva Carta. Em um artigo intitulado "A melodia dos signos", Franklin de Matos nos lembra que, no pensamento de Rousseau, "música e linguagem sempre estiveram associadas". E o exemplo que Matos escolhe para ilustrar essa associação é justamente a Carta sobre a música francesa: 


\begin{abstract}
Nesse texto, cujo alvo principal é o compositor Jean-Philippe Rameau, Rousseau afirma que, se a música italiana é mais capaz de exprimir as paixões que a francesa, é porque privilegia a melodia, e não a harmonia e o contraponto. Tal diferença, aliás, se deve àquilo que distingue os próprios idiomas desses dois povos: enquanto o francês contém poucas vogais sonoras e está cheio de consoantes, articulações e sílabas mudas, o italiano é doce, sonoro, harmonioso e acentuado. (MATOS, 2001, p.163).
\end{abstract}

Isto posto, o que nos interessa reter do posicionamento do filósofo genebrino na querela em questão é o fato de que, como lembra Kintzler, "o princípio da primazia da harmonia sobre a melodia" foi, de fato, "violentamente combatido por J.-J. Rousseau" (KINTZLER, 1983, p.169-170), pelas razões claramente expostas por Franklin de Matos, no contexto dessa "guerra" que eclodiu na cena e nos bastidores da ópera na Paris dos anos 1750.

Como vimos, Rousseau não foi o primeiro a sustentar a superioridade da música italiana com base em todas essas qualidades às quais se refere Franklin de Matos. Assim como os partidários da música francesa (como Madame de Pompadour, Cazotte, entre outros), que se posicionavam do "lado do rei", tampouco foram os mais antigos defensores do patrimônio musical de seu país. Entretanto, como sustenta Fumaroli, mesmo na Querela dos Antigos e dos Modernos, nenhum Antigo teria ido tão longe a ponto de sustentar, como fez Rousseau,

a superioridade ontológica do gênio antigo, acordado com aquele da Natureza, sobre a decadência moral, política e poética dos Modernos, ${ }^{19}$ ou seja, notadamente dos parisienses e de seus filósofos. Nem Boileau, nem mesmo Du Bos teriam ousado escrever, em favor dos Antigos, como Rousseau o fez em seu Ensaio sobre a origem das línguas: "Esses tempos de barbárie [a Antiguidade bíblica e homérica] foram o século de ouro". (FUMAROLI, 2001, p.214; PIMENTA, 2020, p.316).

Ora, conhecemos a conclusão da Carta, que parece ter carregado os bastidores da ópera parisiense, onde a atmosfera - ligeiramente derrisória no início da Querela acabou precipitando uma chuva de impropérios. E não era para menos: nesse mesmo texto, o filósofo-músico de Genebra, como um legislador da música moderna, arrogava a si o direito de condenar a música francesa a uma severa pena, declarando em alto e bom som esta mal-afortunada sentença:

Creio ter mostrado que não há nem ritmo nem melodia na música francesa, porque a língua não os admite; que o canto francês não passa de um contínuo clamor, insuportável a todo ouvido não preconceituoso, que sua harmonia é tosca, sem expressão, soando apenas como exercício de colegial; que as árias francesas não são árias; que o recitativo francês não é recitativo. Do que concluo que os franceses não têm música e não podem tê-la, ou, se alguma vez a tiverem, será tanto pior para eles. (ROUSSEAU, 2005, p.44).

\footnotetext{
19 Lembremo-nos de que tal decadência, a qual, de certa maneira, também é denunciada na Carta sobre a música francesa, já vinha sendo apontada por Rousseau desde o Discurso sobre as ciências e as artes (composto entre 1749 e 1750), até consumar-se em suas análises do Ensaio sobre a origem das línguas (composto entre 1753 e 1754, com acréscimos feitos de 1761 a 1763, e publicado em 1781 , três anos após a morte do autor), e em alguns de seus verbetes do Dicionário de música (composto entre 1753 e 1764).
} 
E seus efeitos nefastos são claramente expostos por Jacques Charpentier, em um artigo cujo título - "J.-J. Rousseau músico marginal?" - já sugere uma aguda provocação a uma linhagem de rancorosos opositores que, ainda hoje, não medem esforços para deslustrar o autor da Carta sobre a música francesa, ao retomar a sentença final desse mal-afamado libelo: “[...] para os músicos franceses, Rousseau aparece em primeiro lugar como aquele que escreveu: 'os franceses não têm música e não podem tê-la; ou, se um dia tiverem uma, tanto pior será para eles'" (CHARPENTIER, 1992, p.513). Entretanto, procurando fazer jus à vocação musical de Rousseau, Charpentier sustenta que essas linhas "célebres e deploráveis" da Carta, "somadas à recordação das disputas incessantes que J.-J. Rousseau manteve com o meio musical de seu tempo, constantemente lhe granjeiam o obstinado rancor da maior parte dos meus colegas compatriotas. Entre eles, ainda hoje, muitos chegam mesmo a recusar-lhe o título de músico...". Naturalmente, conclui Charpentier, é somente

[...] a partir da leitura e do estudo da obra literária e musical de J.-J. Rousseau que nos damos conta de que essas linhas provocantes não deveriam jamais ter sido isoladas do seu contexto polêmico, no qual esse provinciano tímido, incapaz de se fazer admitir nos salões parisienses, trai sua mágoa e suas pretensões não realizadas pela incisividade do seu verbo. (CHARPENTIER, 1992, p.513).

É bem verdade que a Querela dos Bufões compreende a querela entre Rousseau e Rameau, como uma espécie de moldura de um dos episódios do extenso e complexo debate entre esses dois musiciens savants; debate esse que, além de recobrir "múltiplos aspectos da teoria e da prática musicais" (STERN, 2015, p.239), extrapola o próprio domínio da estética musical, como aponta a arguta observação de Catherine Kintzler, a propósito do alcance da Carta sobre a música francesa e do desenvolvimento de sua argumentação em posteriores reflexões do filósofo:

Para além da violência polêmica que a atravessa e que ela suscita [...], a Carta sobre a música francesa enuncia o núcleo teórico do pensamento de Rousseau: ao opor a "melodicidade" da música italiana à complexidade harmônica da música francesa, ela caracteriza a oposição entre o modelo vocal, simples e natural, próprio para exprimir as emoções diretamente, e o modelo articulado, intelectual e material, segundo o qual as línguas e a música vão pouco a pouco se tornando complicadas e degradadas. Essa oposição é a primeira ocorrência de uma longa série que, um pouco mais tarde, o Ensaio sobre a origem das línguas dirá muito claramente em torno de um núcleo filosófico, ao opor, dessa vez, o mundo físico-racional, característico do pensamento clássico, ao mundo "moral" do psiquismo humano. (KINTZLER, 1993, p.131, grifo nosso).

Para dar conta dessa complexidade harmônica da música francesa e, particularmente, dos excessos da harmonia daquele que fora chamado de "destilador de acordes barrocos"20 (ninguém menos que o próprio Rameau), Rousseau recorre à expressividade 
da melodia da música italiana, acompanhada por uma harmonia simples:

\begin{abstract}
Quando se começa a conhecer a melodia italiana, não se encontra nela inicialmente nada que não seja a graça, e acredita-se que ela é apropriada apenas à expressão de sentimentos agradáveis; mas basta estudar um pouco seu caráter comovente e trágico para logo se surpreender com a força que lhe empresta a habilidade dos compositores nas grandes peças de música. É com o auxílio dessas sábias modulações, dessa textura simples e depurada, desses acompanhamentos vivos e brilhantes, que esses cantos divinos dilaceram ou encantam a alma, põem o espectador fora de si, e lhe arrancam, em seus transportes, os gritos com os quais jamais nossas tranquilas óperas foram honradas. Como consegue o músico produzir esses grandes efeitos? Seria à força de contrastar os movimentos, de multiplicar os acordes, as notas, as partes? Å força de empilhar planos sobre planos, instrumentos sobre instrumentos? Todo esse tumulto, que não passa de um mau suplemento ao qual falta o gênio, sufocaria o canto, longe de animá-lo, e destruiria seu interesse ao dividir a atenção. Seja qual for a harmonia que pudessem produzir conjuntamente várias partes, todas bem melódicas, o efeito desses belos cantos desapareceria tão logo se fizessem ouvir simultaneamente, restando apenas o efeito de uma sequência de acordes, que, o que quer que se diga, é sempre frio quando a melodia não os anima, de tal modo que, quanto mais se amontoam despropositadamente os cantos, menos agradável e melodiosa será a música, porque é impossível ao ouvido entregar-se ao mesmo tempo a várias melodias, e, visto que uma apaga a impressão da outra, todo o conjunto só resulta em confusão e barulho. (ROUSSEAU, 2005, p.21).
\end{abstract}

Pautando-se nos exemplares compositores italianos, Rousseau procede então ao desenvolvimento de sua regra da unidade de melodia, ${ }^{21}$ pois, "para que uma música se torne interessante, para que ela leve à alma os sentimentos que nela se quer excitar",

[...] é preciso que todas as partes concorram para fortalecer a expressão do tema; que a harmonia não sirva senão para torná-la mais enérgica; que o acompanhamento a embeleze sem a encobrir nem desfigurar; que o baixo, por uma marcha uniforme e simples, guie de certa forma aquele que canta e aquele que ouve, sem que nem um nem outro disso se apercebam. Em duas palavras: é preciso que o conjunto não leve ao mesmo tempo mais que uma melodia ao ouvido e mais que uma ideia ao espírito. (ROUSSEAU, 2005, p.21).

Como bem lembra Daniela Garcia, coautora da primeira tradução brasileira da Carta sobre a música francesa, foi precisamente neste libelo que Rousseau apresentou, pela primeira vez, sua regra da unidade de melodia (GARCIA, 2008, p.5). Foi a essa mesma regra, como aponta Garcia, que o filósofo recorreu "para apoiar seu ponto de vista estético na crítica à música e ao gosto" dos franceses (GARCIA, 2008, p.5), na medida em que, ainda segundo a autora, Rousseau

\footnotetext{
/ Malgré votre art hétérogène / Lulli de la lyrique scène / Est toujours I'unique soutien. / Fuyez, laissez-lui son partage / Et n'écorchez pas davantage / Les oreilles des gens de bien (Jean-Baptiste Rousseau, Lettre à Louis Racine, 17 novembre 1739, cité par J.M.B. Clément, Joseph de La Porte, Anecdotes dramatiques, Paris, Duchesne, 1775, vol. I, p. 244)" (LEGRAND, 2007, p.119).

21 Cerca de uma década após a Querela dos Bufões, ao concluir seus verbetes que seriam publicados no Dicionário de música, Rousseau se referiu, no final do artigo "Melodia", a essa mesma "unidade de melodia", à qual o filósofo dedicara um verbete inteiro, tamanha a importância que havia adquirido o que ele passaria a chamar de princípio de unidade de melodia, "que os italianos sentiram e seguiram sem o conhecer, e que os franceses, porém, não conheceram nem seguiram" (DAUPHIN, 2008, p.754).
} 
[...] "submete a música francesa à prova [ou ao cadinho] da razão", não com o intuito de verificar se as composições procedem de acordo com regras científicas que a tornariam rígida e fria. Para o autor da Carta, a música não é um objeto físico ou matemático, e a razão à qual ele se refere diz respeito a uma luz interior, a um bom senso que segue as tendências naturais do coração; a razão com a qual Rousseau julga a música francesa [...] é um processo de reconhecimento do comportamento sensível intuitivo e original presente na constituição moral do homem nos primórdios de seu estado de sociedade; comportamento esse comunicado diretamente pelos sinais presentes na língua, sinais que funcionam como identificadores dos sentimentos, das paixões, das emoções e que são indicados principalmente pelos acentos [...]. (GARCIA, 2008, p.79).

Ainda que, para o Rousseau do Ensaio sobre a origem das línguas, a língua italiana também já tenha sofrido certa degeneração, como lembra Garcia, "mostrando-se como língua decadente, sem musicalidade e adaptada às convenções", tal afirmação, "que parece contradizer toda a argumentação da Carta", pode ser bem compreendida se considerarmos "o contexto específico de cada texto" (GARCIA, 2008, p.90). Assim, pontua Garcia (2008, p.91):

[...] a argumentação da Carta [...] se atém a uma problemática estética bem definida, na qual é preciso "tomar um partido", encontrando uma solução plausível. Dentre as soluções possíveis, entre as duas que se apresentam, o italiano parece ser a melhor opção, pois representa uma reconciliação, uma união entre os aspectos artificiais e alguns elementos naturais que ainda sobrevivem intrínsecos a essa língua. O italiano, então, seria o correspondente atual para o que foi a língua grega no passado.

É possível encontrarmos mesmo uma verdadeira consonância entre a Carta e o Ensaio. É o que precisamente aponta, mais uma vez, Garcia (2008, p.91): “É na Grécia anterior ao surgimento dos filósofos e dos sofistas que Rousseau afirma estar a verdadeira música, porque era feita a partir de uma língua natural e espontânea [...]. Na Carta, ao aprofundar sua análise buscando os princípios primeiros de cada elemento da música, Rousseau [...] recorre à música grega". Garcia refere-se precisamente a esta importante passagem da Carta de Rousseau, na qual o autor afirma que

[...] toda música nacional extrai seu principal caráter da língua que lhe é própria, e devo acrescentar que é principalmente a prosódia da língua que constitui esse caráter. Como a música vocal precedeu em muito a instrumental, esta última sempre recebeu da primeira sua maneira de entoar e seu ritmo, e os diversos ritmos da música vocal só puderam nascer das diversas maneiras pelas quais é possível escandir o discurso e dispor as sílabas breves e as longas umas em relação às outras; o que é muito evidente na música grega, da qual todos os ritmos não eram mais que fórmulas rítmicas obtidas por todos os arranjos das sílabas longas ou breves, e dos pés aos quais a língua e a poesia eram suscetíveis. De modo que, embora se possa muito bem distinguir, no ritmo musical, o ritmo da prosódia, o ritmo do verso e o ritmo do canto, não se deve duvidar de que a música mais agradável - ou, ao menos, a mais bem cadenciada - é aquela em que estes três ritmos confluem conjuntamente da melhor maneira possível. (ROUSSEAU, 2005, p.10-11). 
Ao sustentar a tese de que a música de cada nação irá extrair "seu principal caráter da língua que lhe é própria", sendo que é "a prosódia da língua", sobretudo, o que constitui este mesmo caráter - após admitir a possibilidade de se conceber "línguas mais apropriadas à música que outras" e algumas línguas "que the seriam absolutamente inapropriadas" (ROUSSEAU, 2005, p.9) -, Rousseau vincula inextricavelmente música e linguagem ${ }^{22}$, de modo que pode comparar as duas músicas, italiana e francesa, com base, por exemplo, na maior ou menor fluidez da entonação e do ritmo que possuiria a língua de cada uma das duas nações (logo, com base também nas consequências da aplicação da música a uma e outra língua, de acordo com a sua constituição).

Nesse sentido, poderíamos nos perguntar quais seriam as características de uma língua "absolutamente inapropriada" à música. A resposta de Rousseau é clara: esta língua seria "composta apenas por sons mistos, sílabas mudas, surdas ou nasais, poucas vogais sonoras, muitas consoantes e articulações" e um ritmo - "cuja percepção produz em grande parte a beleza e a expressão do canto" - pouco marcado ou imperceptível (ROUSSEAU, 2005, p.9-10). De fato, não é preciso ser adivinho para desvendar, a partir desses elementos, o objeto, ou melhor, a língua que corresponde à descrição feita por Rousseau. Vejamos qual seria o resultado, segundo o filósofo, da "aplicação da música a uma língua assim constituída" (ROUSSEAU, 2005, p.9). Antes de tudo, sustenta Rousseau, "a falta de brilho no som das vogais obrigaria a dar muito mais brilho ao das notas; assim, por ser a língua surda, a música seria esganiçada" (ROUSSEAU, 2005, p.9). Posteriormente, prossegue o filósofo, "a aspereza e a abundância das consoantes forçaria a excluir muitas palavras e a tratar as restantes apenas por entonações elementares, tornando a música insípida e monótona" e, "ainda pela mesma razão", escarnece Rousseau, "seu andamento seria lento e enfadonho, e se quiséssemos apressar um pouco o movimento, sua velocidade assemelhar-se-ia à de um corpo rígido e anguloso rolando sobre o calçamento" (ROUSSEAU, 2005, p.9). Como resultado dessa aplicação, uma vez que "essa música seria incapaz de qualquer melodia agradável", vaticina Rousseau:

[...] procurar-se-ia suprir essa falta por meio de belezas factícias e pouco naturais, sobrecarregando-a de modulações frequentes e regulares, porém frias, sem elegância e sem expressão. Inventar-se-iam os trêmulos, as cadências, os portamentos e outros adornos postiços que se esbanjariam no canto, tornando-o apenas mais ridículo sem deixá-lo menos maçante. Mesmo com toda essa desagradável ornamentação, a música continuaria lânguida e sem expressão, e suas imagens, desprovidas de força e de energia, pintariam poucos objetos em muitas notas, à semelhança dessas escritas góticas cujas linhas repletas de traços e de letras decoradas não contêm mais que duas ou três palavras, e que encerram muito pouco sentido em um grande espaço. A impossibilidade de inventar melodias agradáveis obrigaria os compositores a dirigir todos seus cuidados à harmonia, e, na falta de belezas reais, introduziriam ali belezas de convenção cujo único mérito seria o de ter vencido uma certa dificuldade. Em vez de uma boa música, criariam uma música erudita; para suplementar a melodia, multiplicariam os acompanhamentos; custa-lhes menos empilhar várias partes ruins umas sobre as outras do que compor uma única que fosse boa. Para diminuir a 
insipidez, aumentariam a confusão; acreditariam fazer música e não fariam mais que ruído. (ROUSSEAU, 2005, p.9-10).

Como sabemos, isto foi precisamente o que, para Rousseau, ocorreu com a música francesa. Dessa "falta de melodia", outro efeito que resultaria, segundo o diagnóstico de Rousseau, seria precisamente o fato de que "os compositores, por terem desta apenas uma ideia errônea, encontrariam por toda parte melodias à sua maneira". Logo, "por não terem um canto verdadeiro", multiplicariam "as partes do canto", uma vez que

[...] atrevidamente chamam canto ao que não o é; até mesmo ao baixo-contínuo, em uníssono com o qual fariam recitar sem cerimônia os barítonos, desde que isso thes servisse para recobrir o todo com uma espécie de acompanhamento, cuja pretensa melodia não teria nenhuma relação com a da parte vocal. Por toda parte em que vissem notas, encontrariam canto, já que para eles, efetivamente, o canto não passa de notas. Voces, praetereaque nihil. ${ }^{23}$ (ROUSSEAU, 2005, p.10).

Voltemo-nos agora para o que diz Rousseau sobre a língua italiana e sua natural musicalidade, ao mesmo tempo em que reapresenta os elementos de uma língua que, ao contrário, não seria apropriada à música (leia-se a língua francesa):

Ora, se há na Europa uma língua apropriada à música, é certamente a italiana; pois essa língua é mais doce, sonora, harmoniosa e acentuada que qualquer outra, e essas quatro qualidades são precisamente as mais convenientes ao canto. Ela é doce porque suas articulações são pouco complexas, porque o encontro de consoantes é nela raro e sem aspereza, e porque, dado que um grande número de sílabas é formado apenas por vogais, as frequentes elisões tornam sua pronúncia mais fluente; ela é sonora porque a maior parte das vogais é brilhante, porque não possui ditongos compostos, quase não tem vogais nasais, e porque as articulações esparsas e fáceis distinguem melhor o som das sílabas, que se torna mais nítido e mais cheio. Em relação à harmonia, que depende do número e da prosódia tanto quanto dos sons, a vantagem da língua italiana é evidente neste ponto, pois é preciso observar que o que torna uma língua harmoniosa e verdadeiramente pitoresca ["no sentido de pintar, ou representar as emoções", segundo nota da tradução] depende menos da força real de seus termos do que da distância que existe entre o doce e o forte nos sons que ela emprega, e da escolha que se pode fazer para os quadros que se tem a pintar. (ROUSSEAU, 2005, p.14).

Lembremo-nos de que, ao associar música e linguagem, o filósofo procede de modo a vincular igualmente a melodia à música vocal, cuja anterioridade sobre a música instrumental (justificada pelo modelo dos antigos gregos, que não teriam conhecido a harmonia nem o contraponto) enfraqueceria a autonomia desta última e, por conseguinte, da moderna harmonia e do acompanhamento que, para Rousseau, longe de sustentarem a preeminência do canto, sufocam-no e fazem com que perca sua força e seu brilho. Ademais, não é verdade que música e linguagem estão intimamente ligadas às nossas paixões, uma vez que, para o filósofo e músico genebrino, o canto melodioso, justamente, procura imitá-las por meio de acentuadas inflexões? 
A questão do "gênio" e o problema do "gosto" também terão lugar em suas análises, uma vez que, quando se trata de julgar os estilos nacionais da música italiana e da francesa, Rousseau articulará essas mesmas noções para dar maior força à argumentação em favor da linhagem de Metastasio. ${ }^{24}$

As discussões sobre o gênio ou sobre o gosto musical, as quais se fazem notar sobremodo no elogio da música italiana e nas severas críticas à música francesa, serão também resultantes da argumentação inicialmente apresentada por Rousseau em sua Carta sobre a música francesa e, ao longo de aproximadamente quinze anos, desenvolvida nos artigos que viriam a compor o seu Dictionnaire de musique (concluído em 1764 e publicado em 1768).

No verbete "Compositor" que Rousseau escrevera para a Enciclopédia, vemos as noções de gênio e gosto imbricarem-se de tal maneira que a criação de certa unidade como que inflama ou inspira aquele que compõe música e o aproxima a certos compositores da tradição musical italiana, como Pergolesi, para mencionarmos apenas um exemplo apresentado pelo filósofo (embora este único exemplo seja bastante emblemático, uma vez que se trata do autor de La Serva Padrona, intermezzo que, como vimos, teve um importante papel na abertura da querela que ora abordamos). Uma vez mais, ouçamos Rousseau:

\begin{abstract}
O que entendo por gênio não é esse gosto bizarro e caprichoso que semeia por toda a parte o barroco e o difícil; que só sabe embelezar ou variar a harmonia à força de ruído ou dissonâncias: é esse fogo interior que, incessantemente, inspira cantos novos e sempre agradáveis; expressões vivas, naturais e que se dirigem ao coração; uma harmonia pura, comovente e majestosa. Foi esse divino guia que conduziu Corelli, Vinci, Hasse, Gluck e Rinaldo di Capua ao santuário da Harmonia; Leo, Pergolesi e Terradeglias, ao da expressão e do belo canto. (DIDEROT, 1753, tomo 3, p.769).
\end{abstract}

Ainda sobre esta passagem do verbete "Compositor", é curioso observar que Rousseau assimila o gosto musical degenerado - aquele "gosto bizarro e caprichoso" - ao que ele chama de "barroco" - termo que, aplicado à música, o filósofo definiria da seguinte forma (no verbete homônimo do seu Dicionário de música): "Uma música barroca é aquela em que a harmonia é confusa, carregada de modulações e dissonâncias, o canto duro e pouco natural, a entonação difícil e o movimento forçado" (DAUPHIN, 2008, p.126). Não por acaso, tal definição abarca as características que Rousseau atribui à música francesa e, especialmente, à música de Rameau.

Mas o que afinal faz com que Rousseau prefira a música de Pergolesi à dos franceses e, especialmente, aquela composta por seu arqui-inimigo dijonês? Ora, a resposta está, como bem lembra Bardez, na "clareza" de escritura e no "desenho" 25 perfeito de seu

\footnotetext{
24 Antonio Trapassi, vulgo Pietro Metastasio (1698-1782), poeta, músico e libretista italiano. Em seu Dicionário de música, Rousseau cita o nome desse "genial poeta" nos verbetes "Duo" e "Gênio" (DAUPHIN, 2008, p.302 e 360). O leitor desejoso de conhecer os escritos deste autor, que foi considerado como "o Sófocles italiano", poderá consultar com proveito o volume organizado por Franco Mollia (METASTASIO, 1979).

250 "desenho" [dessein], em música, explica Rousseau (no verbete homônimo do seu Dicionário de música), "é a invenção e a condução do tema, a disposição de cada parte e o ordenamento geral do todo. [...] Essa ideia do desenho geral de uma obra também se aplica particularmente a cada trecho que a compõe. Assim, desenhamos uma ária, um duo, um coro etc." (DAUPHIN, 2008, p.260). Sobre as especificidades do conceito
} 
Stabat Mater, por exemplo. "O tutti de primeiros violinos dobra frequentemente a voz, a orquestra não prolonga (muito frequentemente) a música para além das pausas das árias e, ao precederem estas últimas, enunciam suas melodias pura e simplesmente"; e as "vozes em duo", ainda que não estejam sempre em terças, conclui Bardez, "pronunciam a maior parte do tempo as mesmas sílabas" (BARDEZ, 1980, p.109).

Como bem observou Daniel Paquette, "Rousseau e Rameau não cessaram jamais a polêmica sobre a natureza da ópera italiana repousando sobre a melodia, da ópera francesa, fundada sobre a harmonia" (PAQUETTE, 2006, p.786). Que Rousseau tenha "escolhido o campo dos italianos" em razão da doçura, da sonoridade, do caráter harmonioso, e naturalmente acentuado da língua italiana (qualidades essas que, de acordo com o filósofo, são as mais convenientes ao canto), ou da fluência e simplicidade do recitativo ${ }^{26}$ e das arietas, ${ }^{27}$ cuja "força e variedade das paixões e dos quadros" atestam sua superioridade em relação à música francesa, são argumentos que já reiteramos suficientemente (ROUSSEAU, 2012, p.224). Todavia, como bem aponta Rochat: "Rapidamente o conflito muda de terreno e se politiza: a tragédie lyrique representa o absolutismo governamental face à música italiana mais popular, mais livre, mais conforme às aspirações da futura classe dirigente: a burguesia". No próprio seio do século das Luzes, pondera Rochat, "produz-se uma crise do racionalismo: a procura da expressão verdadeira do sentimento funda uma nova estética em que a efusão do coração traça as vias do romantismo que se avizinha" (ROCHAT, 2012, p.35). ${ }^{28}$ Claro está, portanto, que o que estava em jogo nessa "batalha" - a famosa Guerra dos Bufões -, por mais derrisória que, ainda hoje, possa parecer a alguns, não era tão somente "uma questão de gosto" (ROCHAT, 2012, p.35).

\footnotetext{
de "desenho" no século XVIII, remeto o leitor à tradução do Dicionário de música de Rousseau realizada por José Luis de la Fuente Charfolé, na qual se encontra uma extensa e esclarecedora nota sobre este mesmo termo (FUENTE CHARFOLÉ, 2007, p.178-179, n. 113).

26 No verbete "Estilo", da Enciclopédia, Rousseau se refere ao recitativo (ou "estilo dramático") da seguinte forma: "Estilo dramático ou recitativo é um estilo próprio às paixões. Ver RECITATIVO" (DIDEROT, 1765, tomo 15, p.556). Já no verbete "Recitativo", o autor esclarece que recitativo é "um gênero de canto que se aproxima muito da palavra; é propriamente uma declamação em música, na qual o músico deve imitar, tanto quanto possível, as inflexões de voz do declamador. Por conseguinte, este canto é chamado recitativo, porque se aplica ao relato ou à narração, e o empregamos no diálogo. [...] A língua italiana, doce, flexível e composta de palavras fáceis de pronunciar, permite ao recitativo toda a rapidez da declamação. Aliás, eles desejam que nada de estranho se misture à simplicidade do recitativo, e acreditariam deturpá-lo ao incorporar-lhe quaisquer ornamentos do canto. Os franceses, ao contrário, preenchem o seu recitativo tanto quanto podem. Sua língua, mais carregada de consoantes, mais áspera, mais difícil de pronunciar, demanda mais vagar; e é sobre esses sons desacelerados que eles esgotam as cadências, os acentos, as apojaturas e até as roulades, sem se preocupar muito com a conformidade entre todos esses ornamentos e o personagem ao qual dão voz e as coisas que o fazem dizer. Por isso, nas nossas óperas, os estrangeiros não são capazes de distinguir o recitativo da ária. [...] Seja como for, certo é que, de comum acordo, o recitativo francês se aproxima mais do canto e o italiano, da declamação. Nesse ponto, o que mais é preciso para resolver a questão?" (DIDEROT, 1765, tomo 13, p.854).
}

27 Em seu Dicionário de música, Rousseau define esse termo da seguinte maneira: "ARIETA. s.f. Este diminutivo, oriundo do italiano, significa precisamente pequena ária; mas o sentido dessa palavra é invertido na França, e aí se chamam arietas os grandes trechos de música de um movimento geralmente muito alegre e marcado, os quais são cantados com acompanhamentos de sinfonia e são comumente escritos em rondó (Ver ÁRIA, RONDÓ)" (DAUPHIN, 2008, p.114). 


\section{Referências bibliográficas:}

ARCO JÚNIOR, Mauro Dela Bandera. A palavra cantada ou a concepção de linguagem de Jean-Jacques Rousseau. Orientador: Maria das Graças de Souza. 2012. 162 p. Dissertação (Mestrado em Filosofia) - FFLCH, USP, São Paulo, 2012.

BAECQUE, Antoine de; MELONIO, Françoise. Lumières et liberté: les dix-huitième et dix-neuvième siècles. In: RIOUX, Jean-Pierre; SIRINELLI, Jean-François (dir.). Histoire culturelle de la France. Paris: Éditions du Seuil, t. 3, 2005.

BARDEZ, Jean-Michel. La gamme d'amour de J.-J. Rousseau. Genève: Slatkine, 1980.

BOCCADORO, Brenno. Introduction [Lettre à M. Grimm]. In: ROUSSEAU, JeanJacques. Fuvres complètes. Sous la direction de Raymond Trousson et Frédéric S. Eigeldinger. Écrits sur la musique. Genève: Slatkine; Paris: Champion, t. XII, 2012. p. 207-212.

BORREL, Eugène. La Querelle des Bouffons. In: ROLAND-MANUEL (dir.). Histoire de la musique. II vol. 1. Paris: Gallimard, 2001 [1963]. p. 26-39.

BOUISSOU, Sylvie. Jean-Philippe Rameau: musicien des Lumières. Paris: Fayard, 2014.

CERNUSCHI, Alain. Introduction. In: ROUSSEAU, Jean-Jacques. Euvres complètes. Sous la direction de Raymond Trousson et Frédéric S. Eigeldinger. Écrits sur la musique. Genève: Slatkine; Paris: Champion, t. XII, 2012. p. 175-185.

CHARPENTIER, Jacques. J.-J. Rousseau musicien marginal? In: THIÉRY, Robert. Rousseau, l'Emile et la Révolution: actes du colloque international de Montmorency (27 septembre - 4 octobre 1989). Paris: Universitas/Ville de Montmorency, 1992. p. 513.

COELHO, Lauro Machado. A Ópera na França. São Paulo: Perspectiva, 1999.

DAUPHIN, Claude (ed.). Le Dictionnaire de musique de Jean-Jacques Rousseau: une édition critique. Bern: Peter Lang, 2008.

DIDEROT, Denis. Encyclopédie ou dictionnaire raisonné des sciences, des arts et des métiers. Paris, 1751-1765. 17 v. Edição eletrônica pela Universidade de Chicago, a cargo de Robert Morrissey e Glenn Roe. Disponível em: http://encyclopedie.uchicago.edu/ node/176. 
DIDEROT, Denis; D'ALEMBERT, Jean le Rond. Enciclopédia, ou Dicionário razoado das ciências, das artes e dos ofícios: discurso preliminar e outros textos. V. 1. Org. Pedro Paulo Pimenta, Maria das Graças de Souza. Trad. Fúlvia Moretto e Maria das Graças de Souza. 1. ed. São Paulo: Ed. Unesp, 2015a.

DIDEROT, Denis; D'ALEMBERT, Jean le Rond. Enciclopédia, ou Dicionário razoado das ciências, das artes e dos ofícios: sociedade e artes. V. 5. Org. Pedro Paulo Pimenta, Maria das Graças de Souza. Trad. Maria das Graças de Souza et al. 1. ed. São Paulo: Ed. Unesp, 2015b.

FABIANO, Andrea. La "Querelle des Bouffons" dans la vie culturelle française du XVIII siècle. Paris: CNRS, 2005.

FUENTE CHARFOLÉ, José Luis de la (ed.). Diccionario de música: Jean-Jacques Rousseau.Trad. José Luis de la Fuente Charfolé. Madrid: Akal, 2007.

FUMAROLI, Marc. Les abeilles et les araignées. In: LECOQ, Anne-Marie (ed.). La Querelle des Anciens et des Modernes. Paris: Gallimard, 2001. p. 7-218.

GARCIA, Daniela de Fátima. A música sob a perspectiva crítica de Rousseau: uma análise da Carta sobre a música francesa. Orientador: José Oscar de Almeida Marques. 2008. 147 p. Dissertação (Mestrado em Filosofia) - IFCH, Unicamp, Campinas, 2008.

JACOB, François. De la musique avant toute chose. In: MIRODATOS, Yves (dir.). JeanJacques Rousseau: le sentiment et la pensée. Grenoble: Glénat, 2012. p. 63-71.

KINTZLER, Catherine. Harmonie [2) Primauté de l'harmonie sur la mélodie]. In: BEAUSSANT, Philippe. Rameau de A à Z. Paris: Fayard ; IMDA, 1983. p. 169-170.

KINTZLER, Catherine. La Motte Houdar [Houdard, Houdart], Antoine de. In: BENOIT, Marcelle (dir.). Dictionnaire de la musique en France aux XVII et XVIII siècles. Paris: Fayard, 1992. p. 382.

KINTZLER, Catherine. Introduction à la Lettre sur la musique française. In: ROUSSEAU, Jean-Jacques. Essai sur l'origine des langues: suivi de Lettre sur la musique française et Examen de deux principes avancés par M. Rameau. Paris: Garnier-Flammarion, 1993. p. 129-134.

KÜHL, Paulo Mugayar. A comparação entre a ópera italiana e a francesa: Raguenet e a irredutibilidade de duas tradições. Revista Música, [S. l.], v. 14, n. 1, p. 147-195, maio 2014. 
LANDORMY, Paul. Histoire de la musique. Paris: Librairie Delaplane, [s. d.].

LAUNAY, Denise. La Querelle des Bouffons. Textes des pamphlets avec introduction, commentaires et index. Genève: Minkoff reprint, 1973. 3 v.

LEGRAND, Raphaëlle. Rameau et le pouvoir de l'harmonie. Paris: Cité de la musique, 2007.

MASSIN, Jean; MASSIN, Brigitte. Histoire de la musique occidentale. Paris: Fayard; Messidor, 1985.

MATOS, Franklin de. O filósofo e o comediante: ensaios sobre literatura e filosofia na Ilustração. Prefácio de Bento Prado Júnior. Belo Horizonte: Ed. UFMG, 2001.

METASTASIO, Pietro. Opere: a cura di Franco Mollia. Milano: Garzanti, 1979.

PAQUETTE, Daniel. RAMEAU, Jean-Philippe. In: TROUSSON, Raymond; EIGELDINGER, Frédéric S. Dictionnaire de Jean-Jacques Rousseau. Paris: Honoré Champion, 2006. p. 784-787.

PIMENTA, Pedro Paulo (org.). Rousseau: escritos sobre a política e as artes. Org. Pedro Paulo Pimenta. Trad. Pedro Paulo Pimenta et al. São Paulo: Ubu ; Ed. UnB, 2020.

POT, Olivier. Introduction [Lettre sur l'opéra italien et français]. In: ROUSSEAU, JeanJacques. Fuvres complètes. Écrits sur la musique, la langue et le théâtre. Édition publiée sous la direction de Bernard Gagnebin et Marcel Raymond. Paris: Gallimard, t.V, 1995.p. LXXIV-LXXXI.

POT, Olivier. Notes et variantes [Lettre sur la musique française]. In: ROUSSEAU, JeanJacques. Fuvres complètes. Écrits sur la musique, la langue et le théâtre. Édition publiée sous la direction de Bernard Gagnebin et Marcel Raymond. Paris: Gallimard, t.V, 1995. p. 1448-1494.

RAMEAU, Jean-Philippe. Intégrale de l'EFuvre Théorique: traités, Méthodes, Préfaces, Polémiques et Correspondances. Édition de Bertrand Porot et Jean Saint-Arroman. Bressuire: Éditions Fuzeau Classique, 2008. V. II.

REBATET, L. Une histoire de la musique. Paris: Robert Laffont; Compagnie Française de Librairie, 1995.

RIEMANN, Hugo. Historia de la música. Trad. Antonio Ribera y Maneja. Barcelona: Labor, 1959. 
ROCHAT, Jean-Blaise. Rousseau et la musique. In: DESPOT, Slobodan. Une heure avec Rousseau. Vevey: Xenia, 2012. p. 31-38.

ROUSSEAU, Jean-Jacques. CEuvres complètes. Écrits sur la musique, la langue et le théâtre. Édition publiée sous la direction de Bernard Gagnebin et Marcel Raymond. Paris: Gallimard, t. V, 1995.

ROUSSEAU, Jean-Jacques. Carta sobre a música francesa. Trad. e notas José Oscar de Almeida Marques e Daniela de Fátima Garcia. Campinas: Unicamp; IFCH, 2005. (Textos Didáticos, n. 58).

ROUSSEAU, Jean-Jacques. Confissões. Trad. Rachel de Queiroz (livros I a X) e José Benedicto Pinto (livros XI e XII). São Paulo: Edipro, 2008.

ROUSSEAU, Jean-Jacques. Textos autobiográficos \& outros escritos. Trad., introd. e notas de Fúlvia M. L. Moretto. São Paulo: Ed. Unesp, 2009.

ROUSSEAU, Jean-Jacques. Euvres complètes. In: TROUSSON, Raymond;

EIGELDINGER, Frédéric S. (dir.). Euvres autobiographiques. Genève: Slatkine; Paris:

Champion, t. I. 2012a.

ROUSSEAU, Jean-Jacques. Euvres complètes. In: TROUSSON, Raymond;

EIGELDINGER, Frédéric S. (dir.). Écrits sur la musique. Genève: Slatkine; Paris:

Champion, t. XII, 2012b.

SADIE, Stanley. Dicionário Grove de Música. Ed. concisa. Trad. Eduardo Francisco Alves. Rio de Janeiro: Jorge Zahar, 1994.

STERN, Martin. Jean-Jacques Rousseau, la conversion d'un musicien philosophe. Paris: Honoré Champion, 2015. 